\title{
Interpersonal Interaction Between Nurse and Family to Improve the Performance of Health Center
}

\author{
Siti Nur Kholifah \\ Poltekkes Kemenkes Surabaya Nursing Departement \\ Surabaya, Indonesia \\ Kholifah_stp@yahoo.co.id
}

\begin{abstract}
Family support is a component to provide caring at home. Nurses who established interpersonal interaction with the family will assist in the implementation of nursing actions that have been planned. The purpose of this studied to identify the interpersonal interaction nurses with family to improving the performance of health center nurses. The study used the observational analytic method. The sample was partially nurse at the health center of Surabaya by multistage sampling. The sample size was 110 people. The variables were interpersonal interactions and performance. Data analysis used descriptive analysis and statistical tests with Spearman rho. A half of interpersonal interaction nurse was good. The majority of nurses' performance was good. Spearman rho test results obtained $\mathbf{p}=$ 0.00. It means that was a positive relationship between nurse interpersonal interaction with its performance. Discussion and Interpersonal interaction between family and nurses will improve the performance of nurses in implementation. Nurses need to improve interpersonal interactions with the families to increased performance.
\end{abstract}

Keywords- interaction, interpersonal, nurses, family, performance.

\section{INTRODUCTION}

Nursing care was the performance of nurses. Nurses' performance in implementing the nursing care of families is low. Nurses' performance in implementing the nursing care is still low. The percentage of implementation achievement of nursing care families in East Java is still less than 65\%[1] The one of the reason is that much affluent duty imposed on nurses. The impact performance is not optimal nurses were decreased independence of the family. Family as a responsible care for clients at home providing various facilities to connect clients with the nurse. Erawati (2002) explained that the facility provided an influential family of the treatment provided. Nurses can establish a good interaction with families will allow nurses in performing nursing actions. Families will assist the implementation of nursing activities.

Interaction by King defined as a process of perception and communication that occur in individuals with individuals, individuals and groups, the individual with the environment shown by the behavior of verbal and non-verbal in achieving the goal [2]. Interpersonal interaction is defined as a process of communication between the communicant and communicator are marked with the establishment of mutual understanding, pleasure, mutual influence, good social relations, also ensure that action as feedback [3]. Good interpersonal communication, the more open one reveals himself and the increasingly positive perception of others [4]

Nurse-family interaction has an important role to achieved success in implemented nursing care. Nurses can work with families to continued nursing actions by the schedule programmed by nurses with the family. Nursing action by planning that has been prepared and successfully achieved the goals set with the family, it will improve its performance in implementing family nursing care.

This study explained the relationship between interpersonal interaction nurses and family to nurse's performance in implementing family nursing care.

\section{METHODS}

This study was an observational study with cross-sectional analytic. Its population is a nurse at the health center working area of Surabaya City Health Department D III Nursing education and civil servants amounted to 175 people. The sample in this study is partly a nurse who meets the criteria is 110 people. Sampling by multistage sampling technique. The researched variables include interpersonal interaction with family nurses and nurses' performance in implementing family nursing actions. Data analysis using descriptive and inferential analysis with Spearman rho test. Limit test of significance is 0.05 , so if $\mathrm{p}<0.05$, statistically significant calculations there is a relationship between variables.

\section{RESULT}

The results of this study include characteristics of respondents, the distribution of interpersonal interaction and performance of nurses.

Table 1 illustrates that the largest group of nurses productive age range of 31-40 years. Gender mostly women. Most nurse education is D III Nursing.

Table 2 illustrates the frequency category of interpersonal interaction with family nurse and most of them were catagorized with good interaction. 
TAble 1. Distribution Characteristics of NuRses Health Center in THE CITY OF SURABAYA, 2016

\begin{tabular}{cccc}
\hline No & Characteristics & Number & Percent \\
\hline 1 & Age & & \\
& 20-30 years & 17 & 15,5 \\
31-40 years & 70 & 63,6 \\
& 41-50 years & 14 & 12,7 \\
> 50 years & 9 & $\mathbf{8 , 2}$ \\
\hline 2 & Gender & 38 & 34,5 \\
Male & 32 & 65,5 \\
& Female & & \\
\hline 3 & Education & & \\
& DIII Nursing & 90 & 81.8 \\
& S1 Ners & 19 & 17.3 \\
& S2 Health & 1 & 0.9 \\
\hline
\end{tabular}

TABLE 2. FREQUENCY DISTRIBUTION NURSES INTERPERSONAL INTERACTION WITH FAMILY.

\begin{tabular}{ccc}
\hline $\begin{array}{c}\text { Interpersonal Interaction } \\
\text { Category }\end{array}$ & Number & Percent \\
\hline Good & 55 & 50 \\
\hline Enough & 48 & 43,6 \\
\hline Less & 7 & 6,4 \\
\hline Number & 110 & 100 \\
\hline
\end{tabular}

TABLE 3 FReQUENCY DisTRIBUTION PERFORMANCE NURSE

\begin{tabular}{ccc}
\hline Performance Category & Number & Percent \\
\hline Good & 67 & 60,9 \\
\hline Enough & 41 & 37,7 \\
\hline Less & 2 & 1,8 \\
\hline Number & 110 & 100 \\
\hline
\end{tabular}

TABLE 4. CROSS TABULATION INTERPERSONAL INTERACTION NURSES AND FAMILIES WITH NURSE PERFORMANCE.

\begin{tabular}{|c|c|c|c|c|}
\hline \multirow{2}{*}{$\begin{array}{c}\text { Interpersonal } \\
\text { Interaction } \\
\text { Category }\end{array}$} & \multicolumn{3}{|c|}{ Nurse Performance } & \multirow[t]{2}{*}{ Number } \\
\hline & Good & Enough & Less & \\
\hline Good & $\begin{array}{c}42 \\
(76,36 \%)\end{array}$ & $\begin{array}{c}13 \\
(23,63 \%\end{array}$ & 0 (0\%) & 55 \\
\hline Enough & $\begin{array}{c}25 \\
(52,08 \%)\end{array}$ & $\begin{array}{c}23 \\
(47,92 \%)\end{array}$ & 0 (0\%) & 48 \\
\hline Well & $0(0 \%)$ & $\begin{array}{c}5 \\
(71,43 \%)\end{array}$ & $2(28,57 \%)$ & 7 \\
\hline \multicolumn{5}{|c|}{$P=0,00$} \\
\hline
\end{tabular}

Table 3 explains that the categories of nurses' performance in implementing family nursing actions more than half $(60.9 \%)$ categorized good.

Table 4 illustrates that interpersonal interaction nurse with a family is good, the nurses' performance in implementing family nursing action is also good. Lack of interpersonal interaction nurses, nurse's performance largely on the category enough.

Spearman rho test results obtained $p=0.00$, meaning that there was a significant relationship between interpersonal interaction nurses and family nurse's performance in implemented family nursing actions.

\section{Discussions}

After the text edit has been completed, the paper is ready for the template. Duplicate the template file by using the Save
As command, and use the naming convention prescribed by your conference for the name of your paper. In this newly created file, highlight all of the contents and import your prepared text file. You are now ready to style your paper; use the scroll down window on the left of the MS Word Formatting toolbar.

The family is the closest to the clients at homev[5], [6]. Frey (2003) explained that the family social support affect the health of family members[7]. The family as an influential factor as it can provide reinforcement to family members so treatments on clients to be better [8]. Family support given to sick family members include linking clients with nurses. Spiers A.J. (2002) explain that the interpersonal nurse and family are 1) the territorial or area of responsibility, 2) shared perception of the situation, 3) working relationship fun, 4) the division, 5) knowledge provided to the family, and 6) special topics [9].

Nurses interpersonal interaction with family is a process over the role of nurses to the family. Outstanding interpersonal interaction nurses and families in the process of interaction can be explained by four types of nurses and family relationships [10] as follows: 1) Nurse-helper relationship, the relationship between nurses and aides. Nurses act as nurses and family as a maid. Nurses actions on the nursing a sick family member, the family helps the nurse action. 2) Worker-worker relationship, this type of relationship needs to be negotiated for nurses and families have the same position, namely as a worker. Families cooperate fully with the nurse in learning new skills. The relationship of this type of conflict because the family is overwhelmed, scared or angry because the task is complicated and confusing role of nurses as well as workers and family workers. 3) Manager- worker relationship, the relationship in this type of nurse as a manager, as a family of workers. Nurses gradually shift its role in the family. The nurse will set a limit on their respective roles. Families trained some of the skills necessary to care for sick family members. Nurses monitor the actions taken family, and coordinate actions will be and have been done by nurses and family. 4) The nurse-patient relationship, this type of nurse as a nurse and as a patient's family. The family is seen as the person who needs treatment as patients with chronic diseases. Family records all support services provided to the family members who are sick. Families carry out all instructions given, and nurses perform evaluations of the activities undertaken by the family.

Type of interaction of nurses and family above can explain the importance of interpersonal interaction with family nurses. Nurses who managed to establish interpersonal interaction with family relationship can trust. Mutual trust in the relationship nurse-family set the stage for effective nursing care [6]. Increased self-reliance, nurses create the context for the family to open in the next implementing nursing actions. Families will help implement any nursing actions instructed to family members who are not sick. Nurses who are not 24 hours with clients at home requires the family to help nursing actions already programmed

Interpersonal interactions can be role as an educator for the transfer of knowledge of various knowledge related to the care their family members who are sick and transfer of attitude. It will build a positive attitude for the family to care the family 
members. Nurses also served as an advocate to defend all the interests of a sick family member related to the care provided. Nurses have a role as an empowering of families with increasing capabilities in implementing nursing actions. When all nursing actions planned for the clients at home has been implemented properly, it will affect the success of family nursing care are implemented. Indicators of this success can be evaluated by the achievement of meeting the needs of clients and the independence of the family in caring for family members [11].

Success in implementing family nursing care is an indicator of good performance of the nurses. Performance has a broad sense, is not only measured by the labor, but the process of doing the work are also considered. Wibowo (2014) explains that the performance is about what to do, how to do and the results achieved from such work. The performance of nurses can be defined as the achievement of the quality of nursing services[12]. Performance good nursing brings advantages because it can improve the quality of care. The nursing performance represented an increased felt by clients associated with quality of care such as the reduction of side effects and medication errors [13]. Performance in this researched was the success of family nursing actions with hypertension as provide an understanding of the importance of diet and take medication, exercise gymnastics, and stress management. All nursing action is necessary regularity in its implementation so that the interpersonal interaction with nurses-families are needed. There has been no previous researched results that explained the link interpersonal interaction nurses and family nurse's performance in implementing family nursing actions. The study results represent a novelty to explain nurses and families did the nurses' performance in implementing family nursing actions in terms of interpersonal interaction.

\section{CONCLUSIONS}

Interpersonal interaction with family nurses can improved the performance of nurses in implemented family nursing actions.
Suggestions that can be recommended to the health center nurses in order to improved interpersonal interaction with the family so that all nursing actions can be implemented properly so that the purposed of nursing care family style can be achieved and the performance of nurses will increase.

\section{REFERENCES}

[1] N. K. Erawati, "Relationships family support and the level of depression in the elderly in Puskesmas South Denpasar Denpasar-Bali. Unpublished research report.," 2002.

[2] M. R. Alligood, Nursing Theorists and Their Work. New York: Mosby, 2014

[3] S. L. Tubb and S. Moss, Human Communication: Contex Communication. Badung: Remaja Rosdakarya, 2005.

[4] J. Rachmat., Psikologi Komununikasi. Bandung: Rosdakarya, 2012

[5] M. . Friedman, V. R. Bowden, and E. G. Jones, Family Nursing: Research, Theory \& Practice. New Jersey: Prentice Hall, 2003.

[6] M. R. Friedman, V. R. Bowden, and E. Jones, Family Nursing Research, Theory, and Practice, 4th ed. Philadhelphia: Lipincot williams \& Wilkins, 2010.

[7] M. A. Frey, "Social support and health: A Theoretical formulation derived from Kings conseptual framework," Nurs. Sci. Q. J., vol. 89, no. 2, pp. 138-148, 2003.

[8] E. al. Kholifah, S.N., "The Community Nurse Improving Performance In East Java Through Personal Factors And Commitment," J. Appl. Sci. Res., vol. 4, no. 4, pp. 1-7, 2016.

[9] J. A. Spiers, "The Interpersonal Contexts of Negotiating Care in Home Care Nurse-Patient Interactions," Qual. Health Res., vol. 12, no. 8, pp. 1033-1057, 2002

[10] C. Ward-Griffin and P. McKeever, "Relationships between nurses and family caregivers: partners in care?," Adv. Nurs. Sci., vol. 22, no. 3, pp. 89-103, 2000.

[11] Ministry of Health, Undang-undang Keperawatan. Republic of Indonesia, 2014

[12] Wibowo, Manajemen Kerja. Jakarta: Rajawali Press, 2014

[13] C. . Covel and S. Sidani, "Nursing Intellectual Capital Theory: Implications for Research and Practice," Online J. Issues Nurs., vol. 18, no. 2,2013 